\title{
Triatoma patagonica (Hemiptera, Reduviidae), a New Host for Triatomavirus
}

\author{
Gabriela S Rozas-Dennis/ ${ }^{+}$, Néstor J Cazzaniga, Diego MA Guérin* \\ Departamento de Biología, Bioquímica y Farmacia *Departamento de Física, Universidad Nacional del Sur, San Juan 670, (8000) \\ Bahía Blanca, Argentina
}

Previous authors demonstrated that Triatoma virus $(\operatorname{Tr} V)$ is able to infect several species of triatomines when injected with viral inoculum obtained from its original host, T. infestans. Both vertical (transovarian) and horizontal (faecal-oral) mechanisms of viral transmission were also described. In this paper we report the experimental $\operatorname{TrV}$ infection of a wild species from southern Argentina, T. patagonica. The inoculum consisted of clarified gut contents of infected $\mathrm{T}$. infestans rubbed on the chicken skin whereupon $\mathrm{T}$. patagonica individuals were fed. The results demonstrate that this is another potential host for the virus, and that the oral route is also effective for experimental interspecific infections.

Key words: Chagas disease - picorna-like virus - horizontal transmission

Due to its strictly synanthropic habits and wide geographical distribution, Triatoma infestans (Klug 1834) is the most common vector of Chagas disease in Argentina. However, some wild species, such as Triatoma patagonica Del Ponte 1929, are also able to participate in the life cycle of Trypanosoma cruzi, thus becoming significant in the upkeep of the wild foci of this zooflagellate (Zeledón \& Rabinovich 1981). T. patagonica is the triatomine species reaching the southernmost latitude in Argentina (Argüello 1984), it is frequent within or near human dwelling, and it is extremely aggressive (Abalos \& Wygodzinsky 1951, Lent \& Wygodzinsky 1979). Abalos (1959) assigned epidemiological importance to T. patagonica as a transmitter of Chagas disease in Patagonia. In Bahía Blanca neighbourhoods, this species was identified in samples coming from some precarious houses where $T$. infestans was absent (Rozas-Dennis \& Cazzaniga 1997).

Isolated from $T$. infestans, Triatoma virus ( $\mathrm{TrV})$ is a picorna-like virus belonging to the unnamed family including the Drosophila C virus (Czibener et al. 2000). Infected insects usually die while showing leg paralysis and ecdysis failure (Muscio et al. 1987). Reasonable expectations are held on the potential of this virus for biological control, its pathogenicity in $T$. infestans and vertical, transovarian transmission having been studied by Muscio et al. (1997).

Financial support: Comisión de Investigaciones Científicas de la Provincia de Buenos Aires (CIC) and Universidad Nacional del Sur (Argentina). NJC and DMAG are researchers in CIC and CONICET (Argentina) respectively.

+Corresponding author. Fax: 54-291-459-5130. E-mail: grozas@criba.edu.ar

Received 22 May 2001

Accepted 22 November 2001
Horizontal mechanisms of insect-to-insect transmission through the faecal-oral route were also demonstrated to be involved in the $\mathrm{TrV}$ re-infection of captive populations of T. infestans (Muscio et al. 2000). In this note we report the experimental $\mathrm{TrV}$ infection of $T$. patagonica by contamination of its feeding substratum with gut contents of infected $T$. infestans. This result leads to recognition of T. patagonica as a potential host for $\operatorname{TrV}$ and to demonstrate the effectiveness of the oral infective route for interspecific infections.

\section{MATERIALS AND METHODS}

Live specimens of T. patagonica were collected from chicken houses and human bedrooms, in the neighbourhood of Bahía Blanca city $\left(38^{\circ} 44^{\prime} \mathrm{S}, 62^{\circ} 00^{\prime} \mathrm{W}\right.$, Argentina), and carried to the insectarium once the absence of T. cruzi was confirmed through microscopical analysis of gut contents. They were reared under controlled conditions $\left(27 \pm 2^{\circ} \mathrm{C} ; 60 \pm 5 \% \mathrm{RH}\right)$, fed every 15 days on chickens, and daily checked for external symptoms of viral infection. As neither mortality nor symptoms were detected, 50 individuals were analyzed in order to confirm the absence of viral particles. To do so, fresh faeces from adults and nymphs of the fifth instar were obtained by abdominal compression, and prepared for electron microscopy following the procedures described by Rozas-Dennis et al. (2000). The same methods were applied to whole abdominal contents dissected from sacrificed insects.

Purification techniques by ultracentrifugation, sucrose-gradient analysis and electrophoresis were also applied to check the presence and identity of $\operatorname{TrV}$ (see Rozas-Dennis \& Cazzaniga 2000, for details).

To carry out the experimental infection of $T$. patagonica, insects were fed upon $\operatorname{TrV}$ contaminated substrata, by softly rubbing a surface of $50 \mathrm{~cm}^{2}$ on the esternal region of chickens with $1 \mathrm{ml}$ of a $\operatorname{TrV}$ suspension obtained by clarification (microcentrifugation at $10000 \mathrm{xg}$ for $5 \mathrm{~min}$ ) of gut contents of $\mathrm{TrV}$ infected $T$. infestans. 
Forty $T$. patagonica individuals ( 7 adults, 5 fifth-instar, 1 fourth-instar, 2 third-instar, 1 second-instar, and 24 firstinstar nymphs) were then allowed to feed ad libitum on the contaminated chicken skin. The insects were thereafter kept in an isolated sector of the insectarium, fed every 15 days upon chickens exclusively used for this group, and managed with sterile instruments to avoid any external contamination. They were checked daily to detect any external symptoms of viral disease.

\section{RESULTS}

At the beginning of the essay, no viral particles were observed in the clarified faecal material nor in whole abdominal contents of the 50 individuals from the original colony of $T$. patagonica. The continuous record of UV absorbance at $260 \mathrm{~nm}$ on sucrose gradients sown with purified homogenates did not reveal any peak that should be indicative of the presence of viral particles and, therefore, we assumed that our population of $T$. patagonica was virus-free.

Twenty days after feeding on contaminated surfaces, the insects began to die while showing leg paralysis and ecdysis failure, i.e., the same external symptoms as those demonstrated in infected T. infestans (Muscio et al. 1987). The only groups showing such symptoms in the insectarium were the TrV infected population of T. infestans, from which the inoculum was obtained, and the experimentally treated T. patagonica; the remaining triatomine colonies showed negligible mortality along the experience, as it is normal in non infected colonies.

Mortality affected mostly the youngest nymphs of $T$. patagonica, since 16 out of 24 first-instar nymphs (66.7\%) died during the third week after their first food on the contaminated skin, while only 3 insects among the remaining 16 individuals (18.7\%) died in the same period (2 male adults and 1 fifth-instar nymph). One week after, the single second-instar nymph also died, the remaining individuals staying alive for al least three months.

The sucrose gradients sown with purified

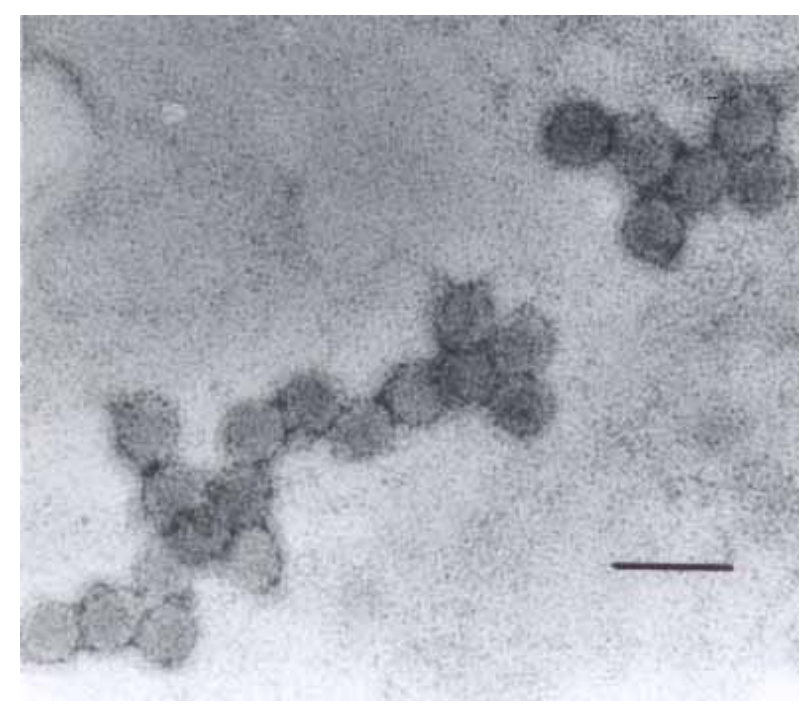

Electron micrograph of Triatoma Virus particles purified from $T$. patagonica, negative stained with $3 \%$ uranyl acetate. Bar $=50 \mathrm{~nm}$ homogenates from symptomatic $T$. patagonica and read at $260 \mathrm{~nm}$, evidenced a single absorbance peak allowing to detect the location of the virus. The fraction under the peak collected with a peristaltic pump showed icosahedrical viral particles, about $30 \mathrm{~nm}$ in diameter (Figure), whose shape and size were undistinguishable from those purified from $T$. infestans. A one-dimensional electrophoresis of the capsid proteins showed four main bands under the BSA control band, corresponding to proteins of 33, 37, 39 and $45 \mathrm{kDa}$, i.e., coincident with the TrV bands VP1, VP2, VP3 and VP0 (Muscio et al. 1988). In Outcherlony double immunodiffusion test, this virus was serologically related to $\mathrm{TrV}$ isolated from $T$. infestans (data not shown).

\section{DISCUSSION}

Host specificity ranges of the insect picorna-like viruses may vary from the very narrow range of the Bee viruses attacking only one or few species in the same genus (Bailey 1976), to the broad range of the Cricket paralysis virus, which infects species in Heteroptera, Orthoptera, Lepidoptera and Diptera (Scotti et al. 1981). In his unpublished thesis, Muscio (1988) mentioned that TrV replicated in four species of Triatoma and Rhodnius prolixus, after being injected with viral material obtained from $T$. infestans. T. patagonica has to be added to the list of potential hosts, and it is the first one to be interspecifically infected through the oral route.

Symptoms and general pathogenicity of $\operatorname{TrV}$ on $T$. patagonica appear to be similar to those demonstrated in its typical host, T. infestans (Muscio et al. 1997, RozasDennis \& Cazzaniga 2000). The origin of the infection in our colony of $T$. patagonica was the experimental contamination with gut contents of infected insects, i.e., an analogous way to the faecal-oral route demonstrated by Muscio et al. (2000) in T. infestans. It is probable that a horizontal reinforcement of the infection occurred among the nymphs of $T$. patagonica by coprophagy after their first meal on the contaminated chicken skin, since coprophagy is a normal behaviour in the triatomines, especially in the nymph instars (Schofield 1979). Sucking haemolymph or blood from the stomach of a companion bug is also a usual behaviour among the triatomines in the insectarium (although we have not observed it during the experience).

The Reduviidae are one of the largest and most diverse families of Heteroptera, the triatomines being a subfamily showing a remarkable uniformity in morphology and habits (Schuh \& Slater 1995). From our results and the indications by Muscio (1988) it appears that this biological evenness also includes a widespread susceptibility to TrV.

\section{ACKNOWLEDGMENTS}

To Drs José La Torre, Oscar Muscio and Osvaldo Fernández for the facilities provided and their friendly encouragement. To Guillermo Villegas for helping with the electrophoretic techniques.

\section{REFERENCES}

Abalos JW 1959. Sobre la importancia epidemiológica de Triatoma patagónico. Rev Fac Med Univ Nac Tucumán 2: 1925.

Abalos JW, Wygodzinsky P 1951. Las Triatominae argentinas 
(Reduviidae, Hemiptera). Univ Nac Tucumán, Inst Med Reg, Publ 601, Monogr 2: 1-178.

Argüello, NEV de 1984. Nota sobre la presencia de Triatoma patagonica Del Ponte, 1929 (Reduviidae, Triatominae) en la provincia de Chubut, Argentina. Rev Soc Entomol Arg 43: 57-59.

Bailey L 1976. Viruses attacking the honey bee. Adv Vir Res 20: 271-304.

Czibener C, La Torre JL, Muscio OA, Ugalde RA, Scodeller EA 2000. Nucleotide-sequence analysis of Triatoma Virus shows that it is a member of a novel group of insect RNA viruses. J Gen Virol 81: 1149-1154.

Lent H, Wygodzinsky P 1979. Revision of the Triatominae (Hemiptera, Reduviidae), and their significance as vectors of Chagas' disease. Bull Amer Mus Nat Hist 163: 123-520.

Muscio OA 1988. Búsqueda de Entomopatógenos y su Evaluación como Posibles Agentes de Control de Triatoma infestans, PhD Thesis, Universidad Nacional de La Plata, 129 pp. (unpublished).

Muscio OA, Bonder MA, La Torre JL, Scodeller EA 2000. Horizontal transmission of Triatoma Virus through the fecal-oral route in Triatoma infestans (Hemiptera: Triatomidae). J Med Entomol 37: 271-275.

Muscio OA, La Torre JL, Scodeller EA 1987. Small nonoccluded viruses from triatomine bug Triatoma infestans (Hemiptera: Reduviidae). J Invert Pathol 49: 218-220.

Muscio OA, La Torre JL, Scodeller EA 1988. Characterization of
Triatoma Virus, a picorna-like virus isolated from the triatomine bug Triatoma infestans. J Gen Virol 69: 2929-2934.

Muscio OA, La Torre JL, Bonder MA, Scodeller EA 1997. Triatoma virus pathogenicity in laboratory colonies of Triatoma infestans (Hemiptera: Reduviidae). J Med Entomol 34: 253-256.

Rozas-Dennis GS, Cazzaniga NJ 1997. Triatominos de Bahía Blanca: respuestas biológicas a la infección con un picornavirus. Medicina 57 (Supl. 3): 85.

Rozas-Dennis GS, Cazzaniga NJ 2000. Effect of Triatoma Virus $(\mathrm{TrV})$ on fecundity and moulting in Triatoma infestans (Hemiptera: Reduviidae). Ann Trop Med Parasitol 94: 633-641.

Rozas-Dennis GS, La Torre JL, Muscio OA, Guérin DMA 2000. Direct methods for detecting picorna-like virus from dead and alive triatomine insects. Mem Inst Oswaldo Cruz 95: 323-327.

Schofield CJ 1979. The behaviour of Triatominae (Hemiptera: Reduviidae): a review. Bull Entomol Res 69: 363-379.

Schuh RT, Slater JA 1995. True Bugs of the World (Hemiptera: Heteroptera). Classification and Natural History, Cornell University Press, Ithaca, $336 \mathrm{pp}$.

Scotti PD, Longworth JF, Plus N, Croizier G, Reinganum C 1981. The biology and ecology of strains of an insect small RNA virus complex. Adv Virus Res 26: 117-143.

Zeledón R, Rabinovich JE 1981. Chagas' disease: an ecological appraisal with special emphasis on its insect vectors. Annu Rev Entomol 26: 101-133. 
T. patagonica, New Host for TrV • Gabriela S Rozas-Dennis et al. 